\title{
Neural network modeling and geochemical water analyses to understand and forecast karst and non-karst part of flash floods (case study on the Lez river, Southern France)
}

\author{
T. Darras ${ }^{1,2}$, F. Raynaud ${ }^{2}$, V. Borrell Estupina ${ }^{2}$, L. Kong-A-Siou ${ }^{3}$, S. Van-Exter ${ }^{4}$, B. Vayssade ${ }^{1}$, \\ A. Johannet ${ }^{1}$, and S. Pistre ${ }^{2}$ \\ ${ }^{1}$ École des mines d'Alès, 6 avenue de Clavières, 30319 Alès CEDEX, France \\ ${ }^{2}$ Hydrosciences Montpellier, Université de Montpelier II, 2 Place Eugène Bataillon, 34095 Montpellier \\ CEDEX 5, France \\ ${ }^{3}$ MAYANE, 173 chemin de Fescau, 34980 Montferrier-sur-Lez, France \\ ${ }^{4}$ Hydrosciences Montpellier, CNRS, Montpellier, 2 Place Eugène Bataillon, 34095 Montpellier CEDEX 5, \\ France \\ Correspondence to: V. Borrell Estupina (Valerie.Borrell@um2.fr)
}

Received: 21 April 2015 - Accepted: 21 April 2015 - Published: 11 June 2015

\begin{abstract}
Flash floods forecasting in the Mediterranean area is a major economic and societal issue. Specifically, considering karst basins, heterogeneous structure and nonlinear behaviour make the flash flood forecasting very difficult. In this context, this work proposes a methodology to estimate the contribution from karst and nonkarst components using toolbox including neural networks and various hydrological methods. The chosen case study is the flash flooding of the Lez river, known for his complex behaviour and huge stakes, at the gauge station of Lavallette, upstream of Montpellier (400 000 inhabitants). After application of the proposed methodology, discharge at the station of Lavalette is spited between hydrographs of karst flood and surface runoff, for the two events of 2014. Generalizing the method to future events will allow designing forecasting models specifically for karst and surface flood increasing by this way the reliability of the forecasts.
\end{abstract}

\section{Introduction}

Flash floods are intense and sudden hydrologic responses of small basins to huge rainfall events. During the past 20 years in southern France they caused more than 100 fatalities and several billions euros of damages. Although, numerous studies have been devoted to flash flooding, hydrologic mechanisms generating flash floods are yet misunderstood. Specifically in case of mixed, karst/non-karst basins, the role of the karst part of the basin is generally unknown. In this context, the aim of this study is thus to improve understanding of karst hydrosystems behaviour during flash flooding. As generally karst basins boundaries are not superposed to those of the surface watershed and have different dynamics, it seems interesting to estimate two different floods: the surface flood and the underground flood, both being finally blended in rivers. To this end, and as it is generally impossible to achieve these measurement on flash floods downstream of the basin, because of the intensity of flood, we propose in this study a methodology which allows to propagate measurements made on or near karst springs (lower discharge) to build discharge at the outlet of the considered basin. First we propose to build a conceptual model of the hydrosystem behaviour (surface watershed and underground basin) and a mathematical expression of the mixture of the two kinds of water. After that, chemical analysis of water near principal karst springs (if there are several springs) allows to estimate relative karst and non-karst contributions to flood. Third, floods coming from different parts of the watershed are propagated towards the outlet using hydrologic models, and the model of mixture 
elaborated in the first part is used to estimate the total contribution of karst and no-karst parts of the flood. To illustrate the methodology, a case-study is chosen on the Lez hydrosystem, well known for its flash floods and important karst role. The Lez karst river crosses the conurbation of Montpellier (400000 inhabitants), providing great damages, and is subjected to strongly heterogeneous and anisotropic water circulation providing highly nonlinear hydrodynamic behaviour.

The paper is thus organized as follows: first, in Sect. 2, the Lez hydrosystem is presented in order to introduce the design of the postulated model and the rainfall-runoff series. In Sect. 3 the behaviour of the hydrosystem is designed thanks to an original utilization of neural networks modelling. In Sect. 4 the propagation of both karst water and surface water is done up to the gauge station of Lavalette. Section 5 allows proposing hydrographs visualizing karst and non-karst contributions. It must be underlined that this study suffers from a lot of approximations and uncertainties due to the lack of measurements; nevertheless it represents a mandatory work preliminary to field works and exhaustive data acquisitions. Targeted field works and measurements, combined with proposed methodology will lead to more accurate estimation of karst contribution to floods, and by this way, to flash flood forecasting improvement.

\subsection{Case study: the Lez aquifer}

The $L e z$ aquifer is a Mediterranean karst system located in southeastern France, upstream Montpellier (Fig. 1). The Lez Spring is the main outlet of this aquifer and the Lez river crosses Montpellier conurbation. Several intermittent springs also exist, among which the Lirou Spring is the most important. In this work we will take in consideration the Lez watershed at Lavalette station, at the entrance of Montpellier, about $120 \mathrm{~km}^{2}$, its sub-watershed, the Triadou watershed, outlet of the Triadou Spring, about $85 \mathrm{~km}^{2}$; and the hydrogeologic basin of around 380 (Bérard, 1983) (Fig. 1).

\subsection{Geological settings}

As most of karst system, the Lez system is composed of karst and non-karst components. The karst component is principally located in the northwestern part of the system. It is composed of Cretaceous and Jurassic carbonate rocks. These formations widely outcrop and form the calcareous plateaus of both Causse de l'Hortus and Causse de Viols-le-Fort (Fig. 1). The Causse de l'Hortus is a perched aquifer. The southeastern part of the system, principally impervious, is composed of Eocene formations as carbonates and clays, and tertiary formations as sandstones, and conglomerates. The major Corconne fault crosses the Lez hydrogeological basin leading to contrasted hydrogeological behaviours.

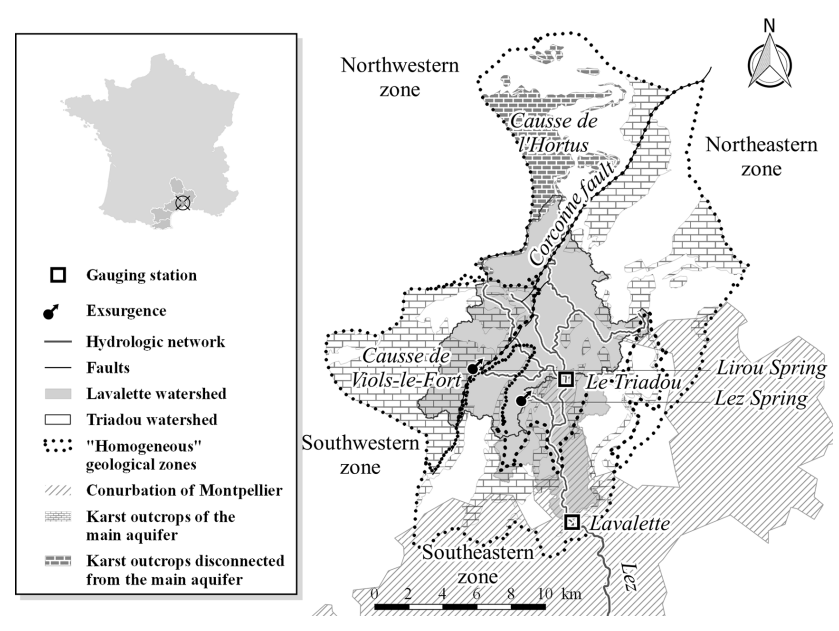

Figure 1. Map of the Lez hydrosystem with location of Le Triadou and Lavalette gauging station, Lez Spring and Lirou Spring.

\subsection{Hydrogeological settings}

The principal aquifer stands in well karstified upper Jurassic and lower Cretaceous limestones. Its bottom limit is the marl and marly limestone layer of the Callovo-Oxfordian formation. Under this layer, thick from 20 to $150 \mathrm{~m}$, stands the middle Jurassic limestone and dolomite aquifer (Bérard, 1983; Marjolet and Salado, 1978). Tectonic accidents affecting the Callovo-Oxfordian layer make water circulation between the both aquifer possible. This water exchanges are not accurately quantified. However, Caetano Bicalho (2010) and Marjolet and Salado (1978) has assessed proportion of water at the Lez Spring coming from the deepest aquifer using both major and trace elements measurements.

The principal aquifer outcrops at the South-West of Lez system (Causse de Viols-le-Fort). Its upper boundary is the lower Valanginian, which outcrops on eastern and northern parts of the Lez system (Fig. 1). The karst aquifer is thus confined under these impervious layers. Infiltration downward aquifer mainly occurred in its southwestern part.

\subsection{Underground circulations}

The Corconne Fault has contrasted roles: in the South part of the basin it behaves as a dam between eastern and western parts of the aquifer. In the North part, it has a drain role thanks to several sinkholes along the fault and its satellites. Communication between northwestern part towards the Lez. Spring were proved by coloration experiments (Marjolet and Salado, 1978).

Based on these findings, a zone division of the Lez basin in four parts has been proposed by Kong-A-Siou et al. (2013) (Fig. 1). The geological composition of each zone is assumed to be "homogeneous", which means that geological similarity is greater inside each zone than outside. The eastwestern division is based on Corconne Fault. On the western 
side of the basin, south-north division has been drawn based on Causse de Viols-le-Fort boundary. On eastern side southnorthen division has been drawn thanks to infiltration properties based on high density of fractures.

\subsection{Climate and meteorology}

The Lez climate is Mediterranean, characterized by two rainy seasons during spring and autumn. Mediterranean rainy events are generally intense and localized providing heterogeneous rainfalls. Heterogeneous rainfall increases thus the sensitivity of the hydrologic response to the location of the rainfalls. It is thus necessary to be able to consider the location of rainfalls and the role of karst and non-karst parts of the basin on infiltration properties.

\subsection{Database}

Database contains one-hour time step data: (i) rainfalls at 5 rain gauges inside or near the basin in order to take into account the heterogeneity of rainfalls, and discharges at Lavallette for 15 intense floods before 2010, and 3 intense floods after 2010. Moreover chemical data are available only for the two last events of 2014 (Table 1). Table 1 focuses on the last events which were investigated in the present work.

\subsection{Lez Flash floods at Lavalette}

Operational flash flood forecasting and early-warning constitute an important field of research (Borga et al., 2011; Price et al., 2011). The task is difficult due to: (i) the lack of knowledge about hydrological processes involved in flash flooding (ii) uncertainty on the rain forecasts, (iii) great noise and uncertainty on measurements especially for the flood peak. In karst system these difficulties are increased due to the necessity to take into account underground process as karst can reduce or increase flood, depending on its saturation prior the event (Jourde et al., 2007; De Waele et al., 2010; BaillyComte et al., 2012; Coustau et al., 2012) at the Lavalette station.

Regarding the Lez floods at Lavalette and considering the high velocity of flash flood genesis, it can be assumed that runoff is the major contributor. Nevertheless, the karst contribution is significant and can worsen significantly the flood. We thus propose a methodology able to estimate separately karst flood and surface flood in order to design two different predictors, for example with neural networks models, as shown by Kong-A-Siou et al. (2011a). The methodology proposes several steps each one achieved and described in this paper in a specific section: (i) establishment of the conceptual model of the basin behaviour (surface and karst), (ii) chemical analysis in order to quantify karst and non karst water, at key points of the basin, were floods don't prevent from making measurements in safe conditions, (iii) propagation of karst and non karst flood up to the outlet of the watershed,
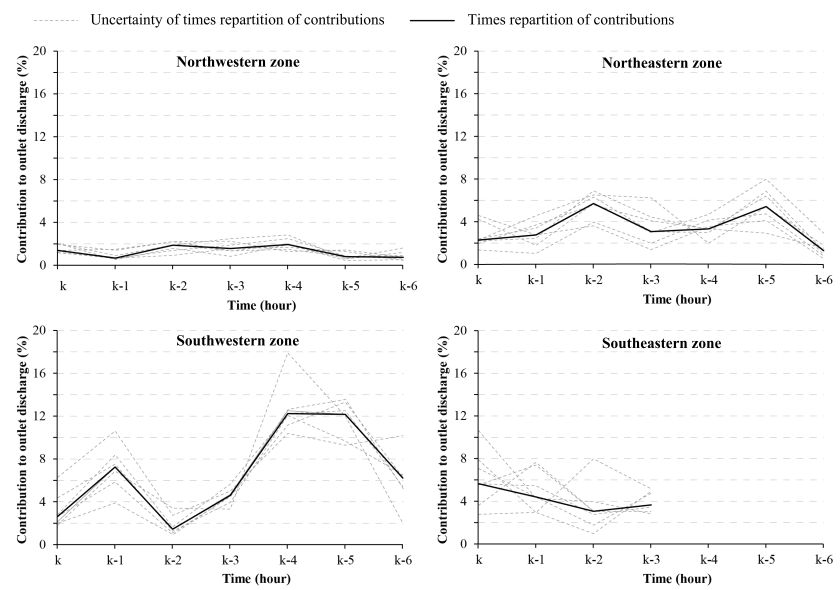

Figure 2. Median and total spread (\%) of respectively northwestern, northeastern, southwestern and southeastern zone contributions versus time.

and finally (iv) reconstitution of the both karst and non karst floods.

\subsection{Elaboration of the conceptual model of the $L e z$ hydrosystem}

Conceptual modelling of the Lez hydrosystem behaviour using neural networks (KnoX method) (Kong-A-Siou et al., 2013) proposed a method able to estimate the contribution of each one of the four zones of the Lez basin to the discharge at the Lez Spring, with daily time step. It appeared that the two northern zones were the most contributory zones to the discharge, sometimes with a 3-day time transfer. Darras et al. (2014) revisited this work at different time and space scales: time step was the hour and only flash floods on the whole basin at Lavalette were considered. The discharge at Lavalette have thus been simulated using artificial neural network fed by mean rainfall, for each of the four zones on several previous time steps, and the previous observed discharge (feed-forward model). The time window widths of previous rainfalls have been sized using method used by Kong-A-Siou et al. (2011b). Table 2 shows the temporal window width of each rainfall zone. Then, as proposed by Kong-A-Siou et al. (2013), model parameters have been analysed to establish contribution of each zone, at each time step of their temporal window width.

One can note on Fig. 2 that northwestern zone (Causse de l'Hortus) has the least contribution and, considering uncertainties on the data, can consequently be excluded from the model. The main contributor is the southwestern zone (almost $50 \%$ on the whole rainfall contribution). The northeastern and southwestern zones both show two peaks of contribution. It seems coherent to attribute the first peak to the surface runoff and the second peak to the karst one, which is slower. One can note that northeastern and southwestern zones are 
Table 1. Dates, peak discharges at Le Triadou and Lavalette gauging stations and mean cumulative rainfalls.

\begin{tabular}{lccc}
\hline Dates & $\begin{array}{c}\text { Peaks discharges at } \\
\text { Lavalette }\left(\mathrm{m}^{3} \mathrm{~s}^{-1}\right)\end{array}$ & $\begin{array}{c}\text { Peaks discharges at } \\
\text { Le Triadou }\left(\mathrm{m}^{3} \mathrm{~s}^{-1}\right)\end{array}$ & $\begin{array}{c}\text { Mean cumulative } \\
\text { rainfalls (mm) }\end{array}$ \\
\hline 29-30 September 2014 & 388 & 370 & 149 \\
6-7 October 2014 & 538 & 445 & 143 \\
\hline
\end{tabular}

Table 2. Temporal window width and contribution of each zone to discharge at Lavalette.

\begin{tabular}{lrrrrr}
\hline & $\begin{array}{r}\text { northwestern } \\
\text { rainfall }\end{array}$ & $\begin{array}{r}\text { northeastern } \\
\text { rainfall }\end{array}$ & $\begin{array}{r}\text { southwestern } \\
\text { rainfall }\end{array}$ & $\begin{array}{r}\text { southeastern } \\
\text { rainfall }\end{array}$ & $\begin{array}{r}\text { Discharge at } \\
\text { Lavalette }\end{array}$ \\
\hline $\begin{array}{l}\text { Temporal } \\
\text { window width }\end{array}$ & $k$ to $k-6$ & $k$ to $k-6$ & $k$ to $k-6$ & $k$ to $k-3$ & Only $k-1$ \\
\hline $\begin{array}{l}\text { Contribution } \\
\text { to discharge }\end{array}$ & $9 \%$ & $26 \%$ & $47 \%$ & $18 \%$ & \\
\hline
\end{tabular}

both upstream Le Triadou. We thus assume that water at Le Triadou is composed of karst and surface water. Moreover downstream Le Triadou the watershed is mainly impervious (southeastern zone) with negligible karst/surface interaction, except the contribution of the Lez spring. The conceptual behaviour of the hydrosystem for flash flooding is thus the following: water coming from the northwestern zone can be neglected, floods coming from both southwestern and northeastern zones are composed of karst water and non-karst water, in unknown proportions, presumably depending on location of rainfalls. The major contribution comes logically from the southeastern impervious zone.

\subsection{Blending model at Lavalette}

Based on the previously presented conceptual understanding of the Lez hydrosystem, a simple model of water blending is proposed. The Le Triadou blend is expressed in Eq. (1):

$Q_{\mathrm{L}}=Q_{\mathrm{T}}^{\mathrm{prop}}+Q_{\mathrm{S}}^{\mathrm{prop}}+Q_{\mathrm{R}}$

were $Q_{\mathrm{L}}$ is the discharge at Lavalette, $Q_{\mathrm{T}}^{\text {prop }}$ is the propagated discharge from Le Triadou to Lavalette, $Q_{\mathrm{s}}^{\mathrm{prop}}$ is the propagated discharge from Lez Spring to Lavalette and $Q_{\mathrm{R}}$ is the additional runoff between Le Triadou and Lavalette. $Q_{\mathrm{L}}$ is known, $Q_{\mathrm{R}}$ is unknown, $Q_{\mathrm{T}}^{\text {prop }}$ and $Q_{\mathrm{S}}^{\text {prop }}$ can be deduced from known discharges at Le Triadou and Lez Spring by a propagation law. To this end we estimated the distances (10 km) and slopes (3\%) between the both stations of Le Triadou and Lez Spring to the Lavalette station. It appeared that as both are equivalent, the same propagation function is then applied to both hydrographs. This propagation was performed using a convolution between the hydrograph and a Gaussian function applied each time step on the 10 previous time steps.

After that is could thus be possible to deduce the unknown surface runoff between Le Triadou and Lavalette from

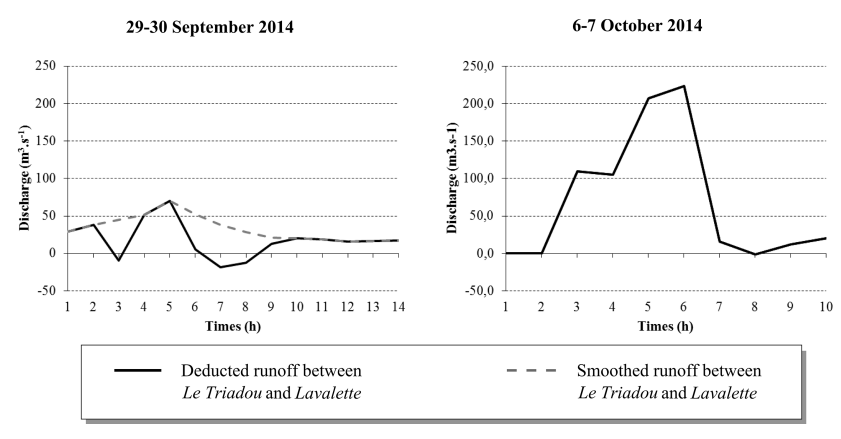

Figure 3. Additional runoff between Le Triadou and Lavalette.

Eq. (1). Unhopefully some negative values appeared which are difficult to explain, as the watershed is essentially impervious in this part of the hydrosystem. Nevertheless, because of the high uncertainty on discharge estimation we proposed to smooth this additional runoff as shown in Fig. 3. Figure 3 shows the smoothed hydrographs of additional runoff, of the event on 29 September and 6 October 2014. One can note that the additional runoff of the October event didn't necessitate smoothing. Maybe this is due to the fact that soils were very wet thanks to the September event.

In order to estimate karst contribution and runoff contribution to the flood, and because this measurement was impossible to proceed at Lavalette station, Raynaud et al. (2015) proposed two functions to evaluate the karst contribution of the discharge at Le Triadou during rise and decrease of the hydrograph. Equations (2) and (3) provide the relation applied for the rise and the recession of the hydrograph.

$$
\begin{array}{ll}
Q_{\mathrm{T}}^{\mathrm{K}}=152.08 Q_{\mathrm{T}}^{-0.302}, & \forall Q_{\mathrm{T}}>15 \mathrm{~m}^{3} \mathrm{~s}^{-1}, \\
Q_{\mathrm{T}}^{\mathrm{K}}=-17.59 \mathrm{Ln}\left(Q_{\mathrm{T}}\right)+137.39, & \forall Q_{\mathrm{T}}>15 \mathrm{~m}^{3} \mathrm{~s}^{-1},
\end{array}
$$

where $Q_{\mathrm{T}}^{\mathrm{K}}$ is the karst component of the discharge at Le Triadou and $Q_{\mathrm{T}}$ is the total discharge at Le Triadou. 


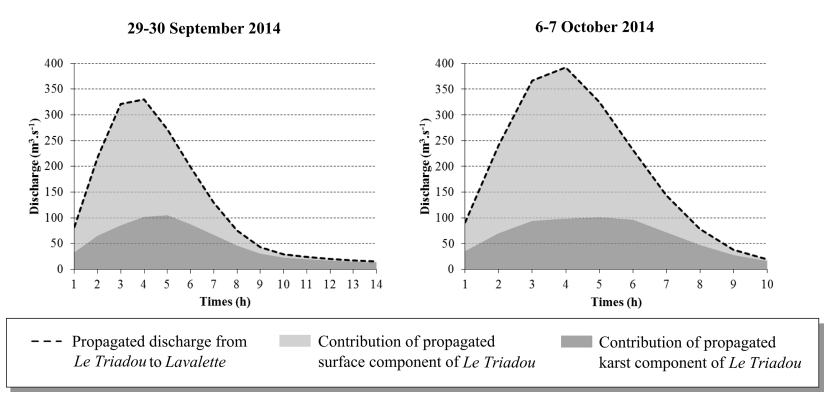

Figure 4. Karst and surface contributions for propagated floods of Le Triadou according Eqs. (2) and (3).

One can thus see on Fig. 4 the repartition of karst and surface contributions to the flood of the events of 29 September and 6 October 2014. One can distinguish a kind of saturation of the karst contribution around $100 \mathrm{~m}^{3} \mathrm{~s}^{-1}$.

Regarding the Lez Spring, one can consider that the discharge is fully karst water as spring is situated in a principally impervious zone.

The karst and surface contributions at Lavalette are then calculated respectively using Eqs. (4) and Eq. (5). Equation (4) expresses that the karst water at Lavalette comes from the whole water of the Lez Spring and the karst part of the Le Triadou discharge, both propagated. Regarding Eq. (5), it expresses that the non-karst water at Lavalette comes from the surface runoff and the part of non-karst water propagated from Le Triadou.

$$
\begin{array}{ll}
Q_{\mathrm{L}}^{\mathrm{K}}=Q_{T^{\mathrm{K}}}^{\text {prop }}+Q_{\mathrm{S}}^{\text {prop }}, & \forall Q_{\mathrm{T}}>15 \mathrm{~m}^{3} \mathrm{~s}^{-1}, \\
Q_{\mathrm{L}}^{\mathrm{S}}=Q_{T^{\mathrm{S}}}^{\text {prop }}+Q_{\mathrm{R}}, & \forall Q_{\mathrm{T}}>15 \mathrm{~m}^{3} \mathrm{~s}^{-1},
\end{array}
$$

where $Q_{\mathrm{L}}^{\mathrm{K}}$ and $Q_{\mathrm{L}}^{\mathrm{S}}$ are respectively the karst and surface contributions at Lavalette and $Q_{T^{\mathrm{K}}}^{\mathrm{prop}}$ and $Q_{T^{\mathrm{S}}}^{\mathrm{prop}}$ are respectively the karst and surface contributions of the discharge propagated from Le Triadou to Lavalette.

\subsection{Karst and surface contribution at Lavalette}

The karst and surface contributions to the discharge at Lavalette were proposed for both events of 29 September and 6 October 2014. The karst contribution and runoff contributions were calculated respectively following Eqs. (4) and (5). Fig. 5 shows hydrographs of the two events analysed splited between their various origins. From bottom to top, contributions from: (i) Lez Spring (karst), (ii) Le Triadou karst component, (iii) runoff between Le Triadou and Lavalette and (iv) Le Triadou surface component.

Regarding the event of 29-30 September 2014, the sum of the four contributions is sometimes higher than the discharge at Lavalette. This misfit is due to the correction of the smoothed contribution of runoff between Le Triadou and Lavalette that have been done before.

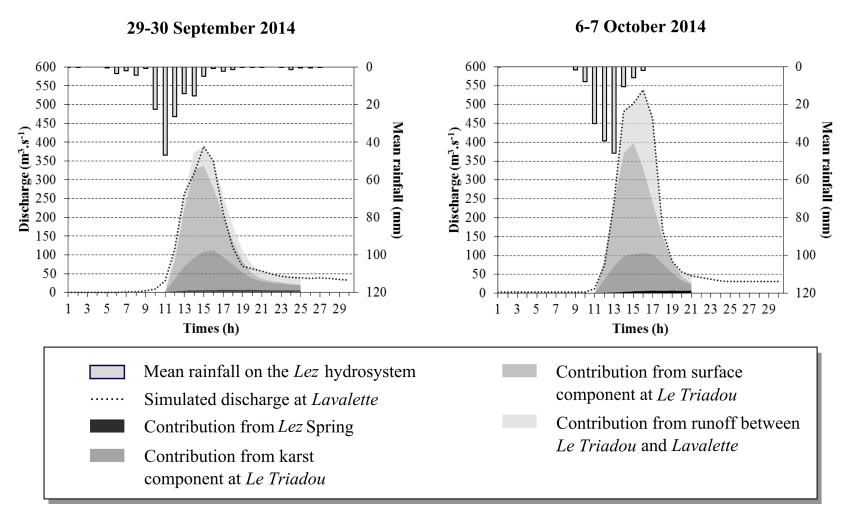

Figure 5. Karst and surface contributions to the discharge at Lavalette.

\section{Discussion}

Concerning both events, although the second event reaches a peak discharge at $150 \mathrm{~m}^{3} \mathrm{~s}^{-1}$ upper than the first one, the karst contribution reaches the same value, around $100 \mathrm{~m}^{3} \mathrm{~s}^{-1}$ in both cases. It seems thus that saturation occurs for karst flood, which seems to be right. The contribution from the $L e$ Triadou surface component is equivalent in both events. The main difference between both events is thus the contribution of runoff between Le Triadou and Lavalette. The application of this method to other intense events could confirm this behaviour of the karst during flash floods.

As the proposed methodology suffers from several approximations and hypothesis due to the lack of measurements and knowledge about the hydrosystem, we thought necessary to present the limitations of this work. First, the main limitation of this study is the choice to estimate the karst contribution at the discharge at Le Triadou as a part of the "total" discharge (karst and surface). This induces thus a systematic synchronisation between "total" discharge and karst contribution. Consequently, the synchronization of karst and surface contributions at Lavalette is not well described by this method while it is known that the karst contribution has a different dynamic than surface contribution, which can be slower or faster depending on the saturation of the hydrosystem prior the event and the rainfall distribution. This drawback could be corrected by measuring directly karst water at the Lirou and other springs. Secondly, the estimation of runoff by difference between total discharge and karst discharge seems also to be inaccurate, probably due to the previous approximation. Third, the propagation of discharges towards the outlet of Lavalette adds uncertainties.

Nevertheless, this method seems to provide an acceptable estimation of karst contribution at each time step. Future field works and data measurements will allow to validate it and to establish accurate karst and non-karst contributions at Lavalette outlet in order to be able to implement an operational flood prediction model based on neural networks. 


\section{Conclusions}

Floods occurring on mixed karst and non-karst basins are very difficult to forecast because of the lack of information about the underlying processes and the different dynamics of the both floods. For this reason we proposed, in this work, a methodology able to estimate both the karst part and the nonkarst part of the flood as separate hydrographs. The Lez basin at Lavalette was chosen as a case study because of its great complexity mixing karst and surface tributaries, and because of great stakes linked to the vicinity of Montpellier conurbation (400 000 inhabitants). Based on a conceptual representation of the Lez hydrosystem behaviour derived from a neural network model, and on the estimation of the distribution of karst and surface components to the discharge at Le Triadou gauging station, we calculated discharge at Lavalette station. The hydrograph at Lavalette was splited into two contributions: the first one representing karst contribution, which seems to saturate around $100 \mathrm{~m}^{3} \mathrm{~s}^{-1}$; the second one representing surface runoff. Distribution between karst and surface hydrographs seems coherent. In order to improve flood forecasting the next step will be the forecasting of each karst and surface contributions separately using artificial neural network models. Reliability of the method could be improved by supplementary field works, specifically measurements of discharge at Lirou spring.

Acknowledgements. The authors would like to thank Bruno Janet and Arthur Marchandise from SCHAPI (Service Central d'Hydrométéorologie et d'Appui à la Prévision des Inondations), the French flood warning service which funded this study. They are also grateful to Meteo France, SPC Med-Ouest and SPC GD which provided data. Our thanks are also extended to Dominique Bertin for his extremely fruitful collaboration within the design and implementation of the Neural Network simulation tool: RnfPro.

\section{References}

Bailly-Comte, V., Borrell-Estupina, V., Jourde, H., and Pistre, S.: A conceptual semidistributed model of the Coulazou River as a tool for assessing surface water-karst groundwater interactions during flood in Mediterranean ephemeral rivers, Water Resour. Res., 48, W09534, doi:10.1029/2010WR010072, 2012.

Bérard, P.: Alimentation en eau de la ville de Montpellier. Captage de la source du Lez étude des relations entre la source et son réservoir aquifère. Rapport no 2: Détermination des unités hydrogéologiques, BRGM Montpellier, 1983.
Borga, M., Anagnostou, E. N., Blöschl, G., and Creutin, J.D.: Flash flood forecasting, warning and risk management: the HYDRATE project, Environ. Sci. Policy, 14, 834-844, doi:10.1016/j.envsci.2011.05.017, 2011.

Caetano Bicalho, C.: Hydrochemical characterization of transfers in karst aquifers by natural and anthropogenic tracers. Example of a Mediterranean karst system, the Lez karst aquifer (Southern France), PhD thesis, AgroParisTech, 2 December, available at: https://pastel.archives-ouvertes.fr/pastel-00569544/document 2010.

Coustau, M., Bouvier, C., Borrell-Estupina, V., and Jourde, H.: Flood modelling with a distributed event-based parsimonious rainfall-runoff model: case of the karstic Lez river catchment, Nat. Hazards Earth Syst. Sci., 12, 1119-1133, doi:10.5194/nhess-12-1119-2012, 2012.

Darras, T., Borrell Estupina, V., Vayssade, B., Kong-A-Siou, L., Johannet, A., and Pistre, S.: Assessment of Contribution of rainfall on "homogenous" geological zones of Lez aquifer (France) to the flash flood genesis: Application of KNOX Method: Conference FRIEND 2014, Montpellier, Communication, doi:10.13140/2.1.3872.4166, 2014.

De Waele, J., Martina, M. L. V., Sanna, L., Cabras, S., and Cossu, Q. A.: Flash flood hydrology in karstic terrain: Flumineddu Canyon, central-east Sardinia, Geomorphology, 120, 162-173, doi:10.1016/j.geomorph.2010.03.021, 2010.

Jourde, H., Roesch, A., Guinot, V., and Bailly-Comte, V.: Dynamics and contribution of karst groundwater to surface flow during Mediterranean flood, Environ. Geol., 51, 725-730, doi:10.1007/s00254-006-0386-y, 2007.

Kong-A-Siou, L., Johannet, A., Borrell, V., and Pistre, S.: Complexity selection of a neural network model for karst flood forecasting: The case of the Lez Basin (southern France), J. Hydrol., 403, 367-380, doi:10.1016/j.jhydrol.2011.04.015, 2011a.

Kong-A-Siou, L., Johannet, A., Borrell-Estupina, V., and Pistre, S.: Optimization of the generalization capability for rainfallrunoff modeling by neural networks: the case of the Lez aquifer (southern France), Environ. Earth Sci., 65, 2365-2375, doi:10.1007/s12665-011-1450-9, 2011b.

Kong-A-Siou, L., Cros, K., Johannet, A., Borrell-Estupina, V., and Pistre, S.: KnoX method, or Knowledge eXtraction from neural network model. Case study on the Lez karst aquifer (southern France), J. Hydrol., 507, 19-32, doi:10.1016/j.jhydrol.2013.10.011, 2013.

Marjolet, G. and Salado, J.: Le système karstique de la source du Lez (Hérault), Méditerranée, 32, 71-83, doi:10.3406/medit.1978.1771, 1978.

Raynaud, F., Borrell-Estupina, V., Pistre, S., Van-Exter, S., Bourgeois, N., Dezetter, A., and Servat, E.: Combining hydraulic model, hydrogeomorphological observations and chemical analyses of surface waters to improve knowledge on karst flash floods genesis, in IUGG, Prague, 2015 (this volume). 